\title{
The relationship between the existence of angiographic coronary artery calcification and the severity of coronary artery disease
}

Związek między zwapnieniami tętnic wieńcowych w angiografii a zaawansowaniem choroby wieńcowej

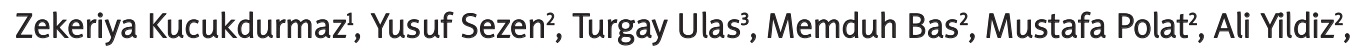 \\ Hakan Buyukhatipoglu³, Zekeriya Kaya², Recep Demirbag² \\ ${ }^{1}$ Department of Cardiology, Cumhuriyet University, Sivas, Turkey \\ 2Department of Cardiology, Harran University, Sanliurfa, Turkey \\ ${ }^{3}$ Department of Internal Medicine, Harran University, Sanliurfa, Turkey
}

Postep Kardiol Inter 2012; 8, 2 (28): 91-95

DOI: 10.5114/pwki.2012.29649

\begin{abstract}
Background: Coronary artery calcification (CAC) is a predictor of coronary artery disease (CAD) and closely related to major adverse cardiac events. The Gensini score is a scoring system to determine the severity and extent of coronary atherosclerosis.

Aim: We aimed to investigate the relationship between CAC and both the extent and severity of CAD.

Material and methods: Coronary artery calcification was identified by visual examination during fluoroscopic examination. The study population was divided into two groups, according to the presence or absence of CAC. The CAC (+) group consisted of 126 patients ( 45 women, 81 men), the CAC $(-)$ group 156 patients ( 58 women, 98 men). Gensini scores were calculated from the results of coronary angiography.

Results: We identified CAC more frequently in type 2 diabetes mellitus patients, with no gender differences. Other risk factors for CAD - including age, hypertension, smoking, body mass index, waist circumference, and systolic blood pressure - were not significantly different between the CAC(+) and CAC(-) groups. Serum levels of triglyceride and very low density lipoprotein (VLDL) cholesterol were significantly lower in the CAC(+) group, and diastolic blood pressure levels and type 2 diabetes mellitus (DM) frequency were higher. By logistic regression, an independent relationship was identified between the Gensini score and CAC.

Conclusions: Coronary calcification seems to be more prevalent in type 2 DM patients than in the normal population. The Gensini score, that is, the extent and severity of coronary artery disease, appears to be independently related to CAC, an issue that warrants further investigation to allow for future clinical applications.
\end{abstract}

Key words: coronary artery calcification, coronary artery disease, Gensini score

\section{Streszczenie}

Wstęp: Wskaźnik zwapnienia tętnic wieńcowych (coronary artery calcification - CAC) jest czynnikiem predykcyjnym choroby wieńcowej (coronary artery disease - CAD) i wiąże się z występowaniem poważnych zdarzeń sercowych. Skala Gensiniego jest systemem punktowym pozwalającym na ocenę zaawansowania i rozległości zmian miażdżycowych w tętnicach wieńcowych.

Cel: Celem badania była ocena związku między CAC a rozległością i zaawansowaniem CAD.

Materiał i metody: Zwapnienia tętnic wieńcowych były wykrywane na podstawie oceny wizualnej podczas fluoroskopii. Badaną populację podzielono na 2 grupy w zależności od obecności CAC. Grupa CAC(+) składała się ze 126 pacjentów (45 kobiet, 81 mężczyzn), a grupa CAC(-) z 156 pacjentów (58 kobiet, 98 mężczyzn). Wskaźnik Gensiniego oceniano na podstawie koronarografii.

Wyniki: Zwapnienia tętnic wieńcowych występowały częściej u pacjentów z cukrzycą typu 2, bez różnic w zależności od płci. Nie stwierdzono istotnych różnic w częstości występowania innych czynników ryzyka CAD, takich jak: wiek, nadciśnienie tętnicze, palenie papierosów, wskaźnik masy ciała, obwód talii oraz skurczowe ciśnienie tętnicze, między pacjentami CAC(+) i CAC(-). Stężenia triglicerydów i cholesterolu VLDL w surowicy były istotnie mniejsze w grupie CAC(+), a rozkurczowe ciśnienie tętnicze oraz częstość

Corresponding author/Adres do korespondencji:

Zekeriya Kucukdurmaz MD, Cardiology Department, Medical School, Cumhuriyet University, 58140, Sivas, Turkey, tel.: 00905336122444 , fax: 00903462191115, e-mail: trimesgites@hotmail.com

Praca wptynęła: 14.09.2011, przyjęta do druku: 11.04.2012. 
występowania DM typu 2 - wyższe. Na podstawie analizy regresji logistycznej stwierdzono niezależny związek między wskaźnikiem Gensiniego a CAC.

Wnioski: Wydaje się, że zwapnienia tętnic wieńcowych występują częściej u pacjentów z cukrzycą typu 2 w porównaniu z populacją ogólną. Wskaźnik Gensiniego, czyli stopień nasilenia choroby wieńcowej, wydaje się niezależnie związany z CAC, co jest zagadnieniem wartym dalszej oceny w celu umożliwienia przyszłych zastosowań klinicznych.

Słowa kluczowe: zwapnienia tętnic wieńcowych, choroba wieńcowa, wskaźnik Gensiniego

\section{Introduction}

Cardiovascular disease is the leading cause of death in the western world and in Turkey [1, 2]. Coronary artery calcification (CAC) is the accumulation of calcification in atherosclerotic plaques, and is an indicator of coronary atherosclerosis [3-7]. It is also a subclinical predictor of future coronary events $[8,9]$. It can be detected by fluoroscopy, multi-slice computed tomography (CT), and intravascular sonography [10]. Risk factors for CAC are similar to those for coronary artery disease (CAD), and include male sex, older age, chronic kidney disease, and low educational status [11, 12]. Many studies have investigated the relationship between CAC and the percentage of coronary artery stenosis; however, no research has been done to determine if any relationship exists between CAC and either the severity or extent of CAD.

\section{Aim}

In this study, we primarily aimed to explore whether there are any such associations.

\section{Material and methods}

\section{Patients and study design}

After the study had been approved by the local ethics committee of Harran University School of Medicine, 282 consecutive CAD patients who had been referred to our clinic for coronary angiography were recruited. All patients provided written informed consent. Patient characteristics and baseline data were recorded. Patients were classified as having hypertension if their blood pressure was over $90 \mathrm{~mm} \mathrm{Hg}$ or systolic blood pressure over $140 \mathrm{~mm} \mathrm{Hg}$; if they were already using hypertensive medication; or if hypertension had already been diagnosed, as indicated in their previous medical records. Diabetes mellitus (DM) was diagnosed in accordance with the ADA criteria, of if the patient was already on diabetes medication. Height, weight and waist circumferences were measured according to a standardized protocol. All patients underwent coronary angiography. We then allocated the patients to one of two groups, according to the presence or absence of CAC. The CAC $(+)$ group consisted of 126 patients (mean age $=63.18$ \pm 9.8 years; 45 women, 81 men), the $C A C(-)$ group 156 patients ( $59.48 \pm 11.0$ years; 58 women, 98 men). Patients without angiographic lesions were considered to be without CAD or normal The severity and extent of coronary atherosclerosis were calculated using Gensini scores.
Exclusion criteria were impaired renal function, unsatisfactory visualization of the coronary arteries, calcification of the aortic valve or mitral annuli, constrictive pericardial disease, and pleural calcification. Type 1 diabetes patients were excluded because of inadequate sample size (5 patients).

\section{Patient catheterization and determining CAC calcification}

All patients were catheterized percutaneously via either the right femoral artery using the standard Judkins technique, or the right brachial artery by the Sones technique. Before we administered opaque material, throughout the coronary artery, trace CAC deposits were identified by visual examination during coronary angiography. Working together, two experienced physicians interpreted each coronary angiogram.

\section{Assigning a Gensini score}

A Gensini score was assigned to each patient as per the published protocol. When generating a Gensini score, as a first step, narrowing of the lumen of any coronary artery is assigned a grade of ' 1 ' for $1-25 \%$ narrowing, ' 2 ' for $26-50 \%$ narrowing, '4' for $51-75 \%$ narrowing, ' 8 ' for $76-90 \%$ narrowing, ' 16 ' for $91-99 \%$ narrowing, and ' 32 ' for total occlusion. This score then is multiplied by a factor that takes into account the importance of the lesion's position in the coronary arterial tree. The position score that is assigned is ' 5 ' for the left main coronary artery; ' 2.5 ' for the proximal left anterior descending (LAD) and proximal left circumflex (LCX; or 3.5 if the LCX is dominant); '1.5' for the mid-region of the LAD; ' 1 ' for the distal LAD, the first diagonal, the proximal right coronary artery (RCA), the mid RCA, the distal RCA, the posterior descending, the distal LCX, the mid LCX (' 2 ' if the LCX is dominant), and the obtuse margin; and ' 0.5 ' for the second diagonal and the posterolateral branch. The final Gensini score is expressed as the sum of all the individual coronary artery scores (14); for example, if a patient had $30 \%$ narrowing of the left main coronary artery, $60 \%$ narrowing of the proximal LAD and $20 \%$ narrowing of the distal LCX, that patient's summation score would be calculated as $(2 \times 5)+(4 \times 2.5)+$ $(1 \times 1)=21$. To aid in the generation of Gensini scores, at least 5 different planes of view were obtained for each patient (right anterior oblique caudal, right anterior oblique cranial, left anterior oblique cranial, left anterior oblique caudal, and antero-posterior cranial). 


\section{Statistical analysis}

All data were analyzed using SPSS version 11.5 (SPSS Inc., Chicago, IL, USA). Continuous variables were expressed as means $\pm \mathrm{SD}$, and categorical variables as percentages. Between-group analyses were assessed by independent Student's $t$-tests for continuous variables and by Pearson's $\chi^{2}$ analysis for categorical variables. Multivariate logistic regression analysis was performed to identify independent predictors of significant CAC. For all statistical analyses, a $p$-value of $<0.05$ was considered statistically significant.

\section{Results}

Clinical characteristics, laboratory variables, and the Gensini scores for the CAC(+) and CAC(-) groups are presented in Table 1. Age, hypertension, cigarette smoking, body mass index (BMI), waist circumference, systolic blood pressure, fasting blood glucose, urea, hemoglobin, and leukocyte and platelet counts were not significantly different between the CAC (+) and CAC(-) groups. Serum levels of triglyceride (155.72 mg/dl vs. $194.42 \mathrm{mg} / \mathrm{dl} ; p<0.028)$ and VLDL cholesterol $(31.00 \mathrm{mg} / \mathrm{dl}$ vs. $40.31 \mathrm{mg} / \mathrm{dl}$; $p<0.023)$ were significantly lower in the $\mathrm{CAC}(+)$ group than in the CAC (-) group. Conversely, diastolic blood pressure levels were higher in the CAC(+) group $(83.06 \mathrm{~mm} \mathrm{Hg}$ vs. $79.52 \mathrm{~mm} \mathrm{Hg} ;=0.038$ ) (Table 1), and DM was seen more frequently (42.0\% vs. $30.5 \%$; $p=0.026)$ (Table 1$)$. Upon logistic regression analysis, the Gensini score was found to be an independent determinant of CAC $(\beta=-0.017$, $\chi^{2}=4.35, p=0.007$ ) (Table 2).

\section{Discussion}

Coronary artery calcification begins shortly after fatty streak formation [13], a finding that should be detectable by microscopic methods [14]. The CAC consists of small aggregates of crystalline calcium amid a core of lipid particles in the atherosclerotic plaque [13-15]. Calcification in the atherosclerotic plaque is an organized, regulated process, similar to bone formation. Non-hepatic Gla-containing proteins, such as osteocalcin, which are actively involved in the transport of calcium out of vessel walls, are suspected to have key roles in the pathogenesis of CAC [7]. Known to be involved in bone mineralization, osteopontin and its mRNA have been identified in calcified atherosclerotic lesions [7]. Calcified human atherosclerotic plaque also contains protein-2a, a potent factor for osteoblastic differentiation, as well as cells that are capable of osteoblastic differentiation. These cells may be those from which vascular calcifying cells are derived. These and other recent findings indicate that calcification is an active process and not simply the passive precipitation of calcium phosphate crystals, as once thought. Thus, it has become well known that accelerated active calcification in the coronary arteries is an indicator of atherosclerosis, and
Table 1. Baseline clinical and laboratory characteristics in subjects with - CAC $(+)$ - and without - CAC $(-)$ - coronary artery calcification

Tabela 1. Podstawowa charakterystyka kliniczna i laboratoryjna pacjentów ze zwapnieniami tętnic wieńcowych - CAC(+) - oraz bez zwapnień - CAC(-)

\begin{tabular}{|c|c|c|c|}
\hline $\begin{array}{l}\text { Clinical and hemodynamic } \\
\text { data }\end{array}$ & $\begin{array}{c}\mathrm{CAC}(-) \\
(n=156)\end{array}$ & $\begin{array}{l}\mathrm{CAC}(+) \\
(n=126)\end{array}$ & Value of $p$ \\
\hline Age [years] & $60 \pm 10$ & $63 \pm 10$ & 0.003 \\
\hline Sex [\% male] & 62 & 64 & 0.768 \\
\hline $\mathrm{BMI}\left[\mathrm{kg} / \mathrm{m}^{2}\right]$ & $27 \pm 5$ & $27 \pm 6$ & 0.525 \\
\hline $\mathrm{BSA}\left[\mathrm{m}^{2}\right]$ & $1.82 \pm 0.20$ & $1.78 \pm 0.22$ & 0.146 \\
\hline $\mathrm{WC}[\mathrm{cm}]$ & $99 \pm 12$ & $100 \pm 13$ & 0.754 \\
\hline BP systolic [mm Hg] & $131 \pm 24$ & $136 \pm 28$ & 0.108 \\
\hline BP diastolic [mm Hg] & $80 \pm 13$ & $83 \pm 15$ & 0.038 \\
\hline Heart rate [beat/min] & $78 \pm 14$ & $78 \pm 13$ & 0.677 \\
\hline APS [mm Hg] & $122 \pm 23$ & $124 \pm 25$ & 0.474 \\
\hline $\mathrm{APD}[\mathrm{mm} \mathrm{Hg}]$ & $62 \pm 13$ & $61 \pm 12$ & 0.501 \\
\hline Diabetes mellitus [\%] & 30 & 42 & 0.007 \\
\hline Hypertension [\%] & 39 & 40 & 0.815 \\
\hline Dyslipidemia [\%] & 39 & 33 & 0.267 \\
\hline Cigarette smoking [\%] & 35 & 29 & 0.348 \\
\hline QT duration [ms] & $383 \pm 41$ & $393 \pm 46$ & 0.078 \\
\hline $\mathrm{QT}_{\mathrm{C}}$ duration $[\mathrm{ms}]$ & $429 \pm 40$ & $436 \pm 36$ & 0.176 \\
\hline Urea [mg/dl] & $37.7 \pm 17.6$ & $42.2 \pm 21.7$ & 0.196 \\
\hline Creatinine $[\mathrm{mg} / \mathrm{dl}]$ & $1.45 \pm 4.59$ & $1.51 \pm 4.61$ & 0.939 \\
\hline Fasting glucose $[\mathrm{mg} / \mathrm{dl}]$ & $129 \pm 60$ & $145 \pm 74$ & 0.197 \\
\hline Total cholesterol [mg/dl] & $199 \pm 49$ & $195 \pm 39$ & 0.660 \\
\hline LDL cholesterol [mg/dl] & $125 \pm 38$ & $129 \pm 38$ & 0.531 \\
\hline HDL cholesterol [mg/dl] & $40 \pm 15$ & $40 \pm 10$ & 0.692 \\
\hline Triglyceride [mg/dl] & $194 \pm 102$ & $156 \pm 76$ & 0.028 \\
\hline VLDL cholesterol [mg/dl] & $40 \pm 22$ & $31 \pm 14$ & 0.023 \\
\hline SGOT $[\mathrm{mg} / \mathrm{dl}]$ & $35 \pm 33$ & $32 \pm 24$ & 0.692 \\
\hline $\mathrm{SGPT}[\mathrm{mg} / \mathrm{dl}]$ & $32 \pm 24$ & $26 \pm 16$ & 0.287 \\
\hline Hemoglobin [g/dl] & $13.3 \pm 1.7$ & $13.4 \pm 1.6$ & 0.763 \\
\hline WBC $[/ \mathrm{ml}]$ & $10.9 \pm 5.7$ & $10.1 \pm 3.7$ & 0.567 \\
\hline Platelet $\left[\mathrm{mm}^{3}\right]$ & $251 \pm 86$ & $282 \pm 97$ & 0.221 \\
\hline Total Gensini score & $27.7 \pm 25.7$ & $43.8 \pm 31.3$ & $<0.0001$ \\
\hline \multicolumn{4}{|c|}{$\begin{array}{l}\text { Values are mean } \pm \text { SD or percentage (\%). Significant differences are } \\
\text { shown in bold }\end{array}$} \\
\hline \multicolumn{4}{|c|}{$\begin{array}{l}\text { APD - aorta pressure diastolic, APS - aorta pressure systolic, BMI- } \\
\text { body-mass index, BSA - body surface area, } H D L \text { - high-density lipopro- } \\
\text { tein, } L D L \text { - low-density lipoprotein, } S G O T \text { - serum glutamic oxaloacetic } \\
\text { transaminase, } S G P T \text { - serum glutamic pyruvic transaminase, TA - ten- } \\
\text { sion arterial, } Q T_{C} \text { - corrected } Q T \text { duration, } V L D L \text { - very low-density } \\
\text { lipoprotein, WBC-white blood cells, WC - waist circumference. Inter- } \\
\text { group statistical comparisons by Student's t-test and } \chi^{2} \text { tests. }\end{array}$} \\
\hline
\end{tabular}

that CAC does not exist on normal vessel walls [16]. However, a clinically more important point pertains to the severity and extent of the atherosclerosis. Consequently, we 
Table 2. Results of correlation and regression analysis to identify predictors of coronary artery calcification (CAC) Tabela 2. Wyniki analiz korelacji i regresji majacych na celu identyfikację czynników predykcyjnych wystąienia zwapnień tętnic wieńcowych (CAC)

\begin{tabular}{lcccc} 
Parameter & B correlation coexistence & Value of $p$ & B regression coexistence & Value of $p$ \\
\hline Age [year] & 0.174 & 0.003 & 0.049 & 0.078 \\
\hline TA dias [mm Hg] & 0.127 & 0.038 & 0.039 & 0.058 \\
\hline Triglyceride & -0.206 & 0.028 & -0.133 & 0.074 \\
\hline VLDL cholesterol & -0.237 & 0.023 & 0.648 & 0.082 \\
\hline Gensini score & 0.273 & $<0.0001$ & 0.017 & 0.007 \\
\hline Diabetes mellitus & 0.124 & 0.023 & 0.548 & 0.347
\end{tabular}

VLDL cholesterol - very low density lipoprotein cholesterol

focused on whether coronary calcification is also an indicator of the severity and extent of atherosclerosis, as well as its presence.

Screening for evidence of CAC is done to evaluate patients with chest pain, to screen asymptomatic subjects, and to follow the progression of coronary atherosclerosis [7]. Coronary artery calcification can be identified using either fluoroscopy or computed tomography. Of these, fluoroscopy is the more frequently used, as we did in this study. The sensitivity of fluoroscopy in determining significant stenosis (greater than $50 \%$ occlusion) in patients with CAC has ranged from $40 \%$ to $79 \%$, and its specificity from $52 \%$ to $95 \%[7,17,18]$.

The results of this study provide several new insights. First, to our knowledge, this is the first study to compare coronary calcification in type 2 diabetics versus non-diabetics. We identified a significant difference between diabetic and non-diabetic patients in terms of CAC, but there was no gender effect, the calcification ratio being no different between males and females. Colhoun et al. previously reported a significant difference between the genders; however, their study was of type 1, not type 2 , diabetics. Their coronary calcification rates were $21 \%$ in non-diabetic females and $47 \%$ in diabetic females, a difference that was not apparent in males (55\% vs. 52\%) [19]. In truth, this result was unexpected and still appears somewhat conflicting. In our study, we found no difference between diabetic and non-diabetic males, or between diabetic and non-diabetic females. However, we studied type 2 diabetes patients. Consequently, the contradictory results between the two studies likely arose because of the different patient populations that were studied.

Another finding of our study was that the frequency of coronary calcification was no different in patients with hypertension or dyslipidemia, or in smokers compared to non-smokers. No other studies have compared CAC in hypertensive and non-hypertensive patients. In two previous studies, coronary calcification was found to be associated with hypertension, but the subjects in both studies were chronic renal failure patients, in whom widespread calcification is not an unusual finding [20,21]. In terms of dyslipidemia, the results of some studies suggest that high- er non-HDL cholesterol is associated with higher, and higher HDL-C with lower electron beam computed tomography (ECBT) CAC scores [22, 23]. In our study, triglyceride (TG) and VLDL levels were elevated in CAC patients, but regression analysis failed to reveal a significant correlation.

Third, when we entered variables that were statistically different between $\mathrm{CAC}(+)$ and $\mathrm{CAC}(-)$ patients (age, diastolic blood pressure, triglyceride, VLDL, diabetes mellitus, and Gensini score) into a regression model, we found that only the Gensini score (extensiveness of coronary artery disease) remained as an independent predictor of CAC. Diabetes mellitus was not found to be an independent determinant of CAC, despite CAC being prominent in diabetes patients. What this tells us is that these other variables exert whatever influence they have through diabetes, rather than directly.

As a fourth finding, though previous studies have shown that calcific deposits are more prevalent and present in greater amounts in elderly individuals and those with more advanced atherosclerotic lesions [15, 16], we identified no such association between the presence or amount of calcific deposits and age.

Finally, perhaps the most important and pioneering finding of this study pertained to the Gensini score, a known determinant of both the severity and extent of coronary artery disease. In this study, the first to have sought any relationship between this score and CAC, we found that it was independently related to CAC.

In conclusion, coronary calcification appears to be more prevalent in type 2 diabetes mellitus patients than in the normal population, though no gender difference exists. Other risk factors for CAD - such as smoking, hypertension, and dyslipidemia - seemed to be unrelated to CAC. Previous studies have demonstrated that the amount of CAC is correlated with the total plaque burden in coronary arteries [4, 16, 24-27]. Our data show that the coronary artery calcification detected by coronary angiography is indeed related to CAD location and severity, through the Gensini score. In other words, the Gensini score (the extensiveness of coronary artery disease) is independently associated with the presence of CAC. Clearly, the usefulness 
and application of this relationship warrant further clinical investigation.

\section{Acknowledgments}

The authors do not report any conflict of interest regarding this work. The poster of this article was awarded as the best poster presentation at the $25^{\text {th }}$ National Cardiology Congress which was held during 22-25 October, 2009 in Istanbul, Turkey. This poster was published in the congress book. This congress was credited by EBAC (European Board for Accreditation in Cardiology).

\section{References}

1. Murray CJ, Lopez AD. Alternative projections of mortality and disability by cause 1990-2020: Global Burden of Disease Study. Lancet 1997; 349: 1498-1504.

2. Onat A. Turkish Heart Report. Yenilik Basımevi, Istanbul 2000.

3. Burke AP, Weber DK, Kolodgie FD, et al. Pathophysiology of calcium deposition in coronary arteries. Herz 2001; 26: 239-244.

4. Frink RJ, Achor RW, Brown AL Jr, et al. Significance of calcification of the coronary arteries. Am J Cardiol 1970; 26: 241-247.

5. McCarthy JH, Palmer FJ. Incidence and significance of coronary artery calcification. Br Heart J 1974; 36: 499-506.

6. Rifkin RD, Parisi AF, Folland E. Coronary calcification in the diagnosis of coronary artery disease. Am J Cardiol 1979; 44: 141-147.

7. Wexler L, Brundage B, Crouse J, et al. Coronary artery calcification: pathophysiology, epidemiology, imaging methods, and clinical implications. A statement for health professionals from the American Heart Association. Writing Group. Circulation 1996; 94 : 1175-1192.

8. Detrano R, Guerci AD, Carr JJ, et al. Coronary calcium as a predictor of coronary events in four racial or ethnic groups. N Engl J Med 2008; 358: 1336-1345.

9. Greenland P, Bonow RO, Brundage RH, et al. ACCF/AHA 2007 clinical expert consensus document on coronary artery calcium scoring by computed tomography in global cardiovascular risk assessment and in evaluation of patients with chest pain. J Am Coll Cardiol 2007; 49: 378-402.

10. Erdogan N, Altin L, Altunkan S. Relationship of artery calcification identified by electron beam tomography with age and gender. Diagnostic and Interventional Radiology 2003; 9: 466-470.

11. Haydar AA, Hujairi NM, Covic AA, et al. Coronary artery calcification is related to coronary atherosclerosis in chronic renal disease patients: a study comparing EBCT-generated coronary artery calcium scores and coronary angiography. Nephrol Dial Transplant 2004; 19: 2307-2312.

12. Yan LL, Liu K, Daviglus ML, et al. Education, 15-year risk factor progression, and coronary artery calcium in young adulthood and early middle age: the Coronary Artery Risk Development in Young Adults study. JAMA 2006; 295: 1793-1800.

13. Stary HC. The sequence of cell and matrix changes in atherosclerotic lesions of coronary arteries in the first forty years of life. Eur Heart J 1990; 11: 3-19.

14. Doherty TM, Detrano RC. Coronary arterial calcification as an active process: a new perspective on an old problem. Calcif Tissue Int 1994; 54: 224-230.

15. Stary HC, Chandler AB, Dinsmore RE, et al. A definition of advanced types of atherosclerotic lesions and a histological classification of atherosclerosis: a report from the Committee on Vascular Lesions of the Council on Arteriosclerosis, American Heart Association. Circulation 1995; 92: 1355-1374.

16. O'Rourke RA, Brundage BH, Froelicher VF, et al. American College of Cardiology/American Heart Association Expert Consensus document on electron-beam computed tomography for the diagnosis and prognosis of coronary artery disease. Circulation 2000; 102: 126-140.

17. Detrano R, Froelicher V. A logical approach to screening for coronary artery disease. Ann Intern Med 1987; 106: 846-852.

18. Detrano R, Salcedo EE, Hobbs RE, Yiannikas J. Cardiac cinefluoroscopy as an inexpensive aid in the diagnosis of coronary artery disease. Am J Cardiol 1986; 57: 1041-1046.

19. Colhoun HM, Rubens MB, Underwood SR, Fuller JH. The effect of type 1 diabetes mellitus on the gender difference in coronary artery calcification. J Am Coll Cardiol 2000; 36: 2160-2167.

20. Haydar AA, Covic A, Colhoun H, et al. Coronary artery calcification and aortic pulse wave velocity in chronic kidney disease patients. Kidney Int 2004; 65: 1790-1794.

21. Megnien JL, Simon A, Lemariey M, et al. Hypertension promotes coronary calcium deposit in asymptomatic men. Hypertension 1996; 27: 949-954.

22. Margolis JR, Chen JT, Kong Y, et al. The diagnostic and prognostic significance of coronary artery calcification: a report of 800 cases. Radiology 1980; 137: 609-616.

23. Orakzai SH, Nasir K, Blaha M, et al. Non-HDL cholesterol is strongly associated with coronary artery calcification in asymptomatic individuals. Atherosclerosis 2009; 202: 289-295.

24. Hamby RI, Tabrah F, Wisoff BG, Hartstein ML. Coronary artery calcification: clinical implications and angiographic correlates. Am Heart J 1974; 87: 565-570.

25. Bierner M, Fleck E, Dirschinger J, et al. Significance of coronary artery calcification: relationship to localization and severity of coronary artery stenosis. Herz 1978; 3: 336-343.

26. Hung J, Chaitman BR, Lam J, et al. Noninvasive diagnostic test choices for the evaluation of coronary artery disease in women: a multivariate comparison of cardiac fluoroscopy, exercise electrocardiography, and exercise thallium myocardial perfusion scintigraphy. J Am Coll Cardiol 1984; 4: 8-16.

27. Tanenbaum SR, Kondos GT, Veselik KE, et al. Detection of calcific deposits in coronary arteries by ultrafast computed tomography and correlation with angiography. Am J Cardiol 1989; 63: 870-872. 